\title{
Pemberdayaan dan Pendampingan Anak Terlantar di Panji Berbakat Anak di Kelurahan Baru Ulu Balikpapan Budha Maryanti ${ }^{*}$; A. Asni B. ${ }^{2}$ \\ ${ }^{1}$ Fakultas Teknologi Industri, Universitas Balikpapan \\ 1*E-mail : budha maryanti@yahoo.com
}

\begin{abstract}
Abstrak
Di beberapa sudut kota, sering ditemukan anak-anak terlantar yang berkeliaran di sekitar jam sekolah dan terlibat dalam kegiatan yang kurang produktif yang mengganggu ketenangan masyarakat, yang membuat mereka jatuh ke pengguna narkoba. Ini harus menjadi perhatian masyarakat mulai dari rumah tangga hingga pemerintah kota. Di Balikpapan, khususnya daerah Kelurahan Baru Ulu yang merupakan kota tua dan padat penduduk dengan kompleks perumahan sangat padat, daerah ini juga disebut zona rawan narkoba. Melalui program pengabdian masyarakat ini dapat memberikan solusi untuk perawatan anak-anak terlantar melalui dukungan yang tepat dan sistem pembelajaran untuk anak-anak terlantar di "Rumah Penampungan" dan PKBM (Pusat Kegiatan Belajar Masyarakat), dengan menggunakan sistem pendidikan non formal sesuai dengan standar yang ditetapkan yang disebut “ Rumah Singgah Peduli Anak Penerus Bangsa”. Kegiatan ini telah dilakukan dan akan terus dilakukan dan menjadi referensi dalam kegiatan tata kelola rumah singgah tersebut.
\end{abstract}

Kata Kunci: Rumah singgah, anak terlantar

\section{Abstract}

In some corners of the city, it is often found abandoned children who roam around school hours and engage in less productive activities that disturb the peace of the community, which makes them fall into drugs. This should be a concern of the community starting from the household to the city government. In Balikpapan, specifically the Kelurahan Baru Ulu area which is an old and densely populated city with a very dense housing complex, this area is also called the drug-prone zone. Through this community service program can provide solutions for the care of neglected children through appropriate support and learning systems for abandoned children in "Shelter Houses" and PKBM (Community Learning Centers), using non-formal education systems in accordance with established standards called " Rumah Singgah Peduli Anak Penerus Bangsa ". This activity has been carried out and will continue to be carried out and become a reference in the shelter management activities.

Keywords: Community Learning Centers, Shelter Houses

\section{Pendahuluan}

Anak adalah setiap manusia yang berusia di bawah 18 tahun dan belum menikah, termasuk anak yang masih dalam kandungan. Secara hukum, pengertian anak diletakkan sebagai objek sekaligus subjek utama dalam suatu proses legitimasi, generalisasi dan sistematika aturan yang mengatur tentang anak. Perlindungan secara hukum ini yang akan memberikan perlindungan terhadap eksistensi dan hak-hak anak (Kamil, 2008).

Beberapa tahun terakhir ini di Indonesia, perhatian pemerintah dan publik terhadap kehidupan anak-anak semakin meningkat. Semakin tumbuh dan berkembangnya organisasi kemasyarakatan yang bergerak di bidang perlindungan anak sebagai salah satu bukti masih tingginya tingkat perasaan kemanusiaan di masyarakat. Namun di balik itu semua ternyata semakin tingginya perhatian yang diberikan oleh pemerintah dan masyarakat ini tidak berdampak berbanding lurus terhadap penurunan jumlah anak terlantar, tingkat kekerasan terhadap anak, perburuhan anak di bawah umur dan lain sebagainya. Kondisi anak-anak Indonesia yang kurang beruntung ini kian hari semakin kurang menggembirakan terutama bila dilihat dari sektor ekonomi dan pendidikan yang didapatnya.

Pada beberapa sudut kota, sering dijumpai anak terlantar yang berkeliaran di jam-jam sekolah dan melakukan aktifitas yang kurang produktif yang cenderung meresahkan masyarakat dan sangat disayangkan sebagian besar aktifitas mereka itu menjerumuskan ke pergaulan yang tidak benar seperti narkoba, mengisap lem secara bersama - sama yang menjadi cikal bakal mereka menjadi dekat dengan narkoba hal ini menjadi perhatian oleh masyarakat dari tingkat Rukun Tetangga (RT) sampai dengan 
pemerintah kota. Umumnya kantung kantung kelompok anak - anak terlantar ini berada di pemukiman padat penduduk dengan taraf ekonomi yang rendah. Adapun data yang kami peroleh yang ada di Balikpapan yang khususnya daerah Baru Ulu sebagian dari kota tua dan padat penduduk dengan tatanan pemukiman yang sangat padat dan banyak dijumpai bangunan tua menjadi salah satu wilayah dan dalam catatan berbahaya atau disebut juga zona rawan narkoba.

Menurut data Rumah Singgah Peduli Anak Penerus Bangsa Kelurahan Baru Ulu Kecamatan Balikpapan Barat Kota Balikpapan yang dalam hal ini disampaikan oleh Ketua Rumah Singgah Peduli Anak Penerus Bangsa, Jalan Sultan Hasanuddin Rukun Tetangga (RT) 38 Kelurahan Baru Ulu, anak terlantar di Wilayah Kelurahan Baru Ulu pada pada tahun 2017 mencapai 100 anak. Dijelaskannya pula, dari jumlah itu, baru 60 anak terlantar yang dibina oleh Rumah Singgah Peduli Anak Penerus Bangsa.

Melalui program pengabdian masyarakat ini diharapkan mampu memberi solusi penanganan anak anak terlantar dan perlu pengaturan sistem belajar mengajar yang tepat bagi anak terlantar. Diharapkan dengan menjaga keseimbangan antara masing-masing aktifitas ini akan menimbulkan rasa keinginan dan kemauan yang lebih besar bagi anak terlantar untuk mengubah kehidupannya ke arah yang lebih baik.

Tujuan dari pembinaan pemberdayaan dan pendampingan anak terlantar di Panji Berbakat Anak di Kelurahan Baru Ulu Balikpapan adalah:

menghindarkan generasi muda usia dini dari bahaya penggunaan narkoba, kenakalan remaja serta kegiatan yang tidak bermanfaat lainnya dengan memberikan wadah agar bisa belajar yang lebih baik dan dapat mengembangkan kemampuan yang dimilikinya.

Sasaran pembinaan pemberdayaan dan pendampingan anak terlantar di Panji Berbakat Anak di Kelurahan Baru Ulu Balikpapan adalah anak-anak mulai usia prasekolah sampai remaja antara 4 sampai 15 tahun.

Anak terlantar, pada hakekatnya adalah "anakanak", sama dengan anak-anak lainnya yang bukan anak terlantar. Mereka membutuhkan pendidikan. Pemenuhan pendidikan itu haruslah memperhatikan aspek perkembangan fisik dan mental mereka. Sebab, anak bukanlah orang dewasa yang berukuran kecil. Anak mempunyai dunianya sendiri dan berbeda dengan orang dewasa. Kita tak cukup memberinya makan dan minum saja, atau hanya melindunginya di sebuah rumah, karena anak membutuhkan kasih sayang. Kasih sayang adalah fundamen pendidikan. Tanpa kasih, pendidikan ideal tak mungkin dijalankan.

Anak terlantar sesungguhnya adalah anak -anak yang masuk kategori anak rawan atau anak -anak yang membutuhkan perlindungan khusus (children in need of special protection). Anak rawan sendiri pada Volume 1, Nomor 2, 2019

ISSN 2657-1439 (Print), ISSN 2684-7043 (Online) dasarnya adalah sebuah istilah untuk menggambarkan kelompok anak-anak yang karena situasi, kondisi, dan tekanan-tekanan kultur maupun struktur menyebabkan mereka belum atau tidak terpenuhi hak-haknya, dan bahkan acap kali pula dilanggar hak-haknya.

Perlindungan anak adalah segala usaha yang dilakukan untuk menciptakan kondisi agar anak dapat melaksanakan hak dan kewajibannya demi perkembangan dan pertumbuhan anak secara wajar baik fisik, mental, dan sosial. Kegiatan perlindungan anak membawa akibat hukum, baik kaitannya dengan hukum tertulis maupun tidak tertulis. Hukum merupakan jaminan bagi kegiatan perlindungan anak. Sebagai salah satu unsur yang harus ada di dalam negara hukum dan demokrasi, perlindungan terhadap hak-hak asasi manusia termasuk di dalamnya perlindungan terhadap anak yang kita harapkan sebagai penentu masa depan bangsa Indonesia dan sebagai generasi penerus harus mendapatkan pengaturan yang jelas. Perlindungan anak merupakan perwujudan adanya keadilan dalam suatu masyarakat, dengan demikian perlindungan anak diusahakan dalam berbagai bidang bernegara dan bermasyarakat (Gultom, 2013).

Anak-anak perlu mendapat kesempatan yang seluas-luasnya untuk tumbuh dan berkembang secara optimal, baik fisik, mental maupun sosial, dan akhlak mulia. Perlu dilakukan upaya perlindungan untuk mewujudkan kesejahteraan anak, dengan memberikan jaminan terhadap pemenuhan hak-haknya dan perlakuan tanpa diskriminasi (Djamil, 2013).

Dilihat dari hak anak-anak ini, mereka mempunyai hak yang harus dipenuhi oleh orangtuanya yaitu hak untuk memperoleh pendidikan yang layak, pengembangan diri dan mental, menyatakan pendapat dan berpikir, memperoleh kebutuhan jasmani dan rohani, memperoleh sarana bermain dan berekreasi serta hak untuk memperoleh pelayanan kesehatan yang memadai Ketika hak - hak anak tersebut tidak terpenuhi, tidak ada perhatian dari orang tuanya maka anak ini dapat dikatakan sebagai anak terlantar. Seorang anak yang tidak mempunyai kedua orang tua atau tidak ada pengampunya akan dikatakan anak terlantar, tetapi seorang anak dapat juga dikatakan terlantar ketika hak-hak anak tersebut tidak terpenuhi secara wajar atau keseluruhan.

Pasal 23 dan Pasal 24 Undang-Undang tentang Perlindungan Anak mengatur mengenai jaminan negara dan pemerintah atas penyelenggaraan perlindungan anak. Negara dan pemerintah menjamin perlindungan, pemeliharaan dan kesejahteraan anak dengan memperhatikan hak dan kewajiban orang tua, wali, atau orang lain yang secara hukum bertanggungjawab terhadap anak. Negara dan pemerintah juga menjamin anak untuk menggunakan haknya dalam menyampaikan pendapat sesuai dengan usia dan tingkat kecerdasan anak. Jaminan yang 
diberikan oleh negara dan pemerintah tersebut diikuti pula dengan pengawasan dalam penyelenggaraan perlindungan anak. Kewajiban dan tanggung jawab masyarakat atas perlindungan anak sebagaimana diatur dalam Pasal 25. Kewajiban dan tanggung jawab masyarakat terhadap perlindungan anak dilaksanakan melalui kegiatan peran masyarakat dalam penyelenggaraan perlindungan anak.

Dengan menjaga dan menghargai kreatifitas anak terlantar, maka diharapkan mereka akan menemukan solusi secara mandiri bagaimana cara untuk mengubah kondisi kehidupannya saat ini menjadi ke arah yang lebih baik lagi. Untuk menjaga kreatifitas anak-anak terlantar, maka diperlukan suatu wadah baik formal maupun informal yang dapat menampung berbagai kreatifitas mereka.

Elemen masyarakat yang terlibat dalam perlindungan anak bukan hanya orang perorangan tetapi juga melibatkan organisasi-organisasi masyarakat, Lembaga Swadaya Masyarakat, Komisi Perlindungan Anak, organisasi-organisasi lain yang memiliki kepedulian terhadap perlindungan anak (Fitriani, 2016).

Pendidikan luar sekolah yang sesuai adalah dengan melakukan proses pembelajaran yang dilaksanakan dalam wadah "Rumah Singgah" dan PKBM (Pusat Kegiatan Belajar Masyarakat), yaitu anak terlantar dilayani Rumah Singgah, sedangkan anak rentan ke jalan dan orang dewasa dilayani dalam wadah Pusat Kegiatan Belajar Masyarakat (PKBM).

Rumah singgah dan PKBM itu dipadukan dengan sekaligus menerapkan pendekatan kelompok dan CBE (Community based Education, pendidikan berbasis masyarakat) serta strategi pembelajaran partisipatif dan kolaboratif (participative and collaborative learning strategy), diharapkan dengan menjaga keseimbangan antara masing-masing aktifitas ini akan menimbulkan rasa keinginan dan kemauan yang lebih besar bagi anak terlantar untuk mengubah kehidupannya kearah yang lebih baik (Syarifuddin, 2015).

\section{Bahan dan Metode}

Tahap dalam pelaksanaan pengajaran dan edukasi anak terlantar merupakan urutan langkah yang dilaksanakan secara sistematis dan logis sesuai dasar teori permasalahan sehingga didapat hasil yang akurat untuk mencapai tujuan pelaksanaan. Dibawah ini adalah flow chart atau diagram alir pelaksanaan pengajaran dan edukasi anak terlantar dan Standart Operating Procedure (SOP) "Rumah Singgah Peduli Anak Penerus Bangsa".

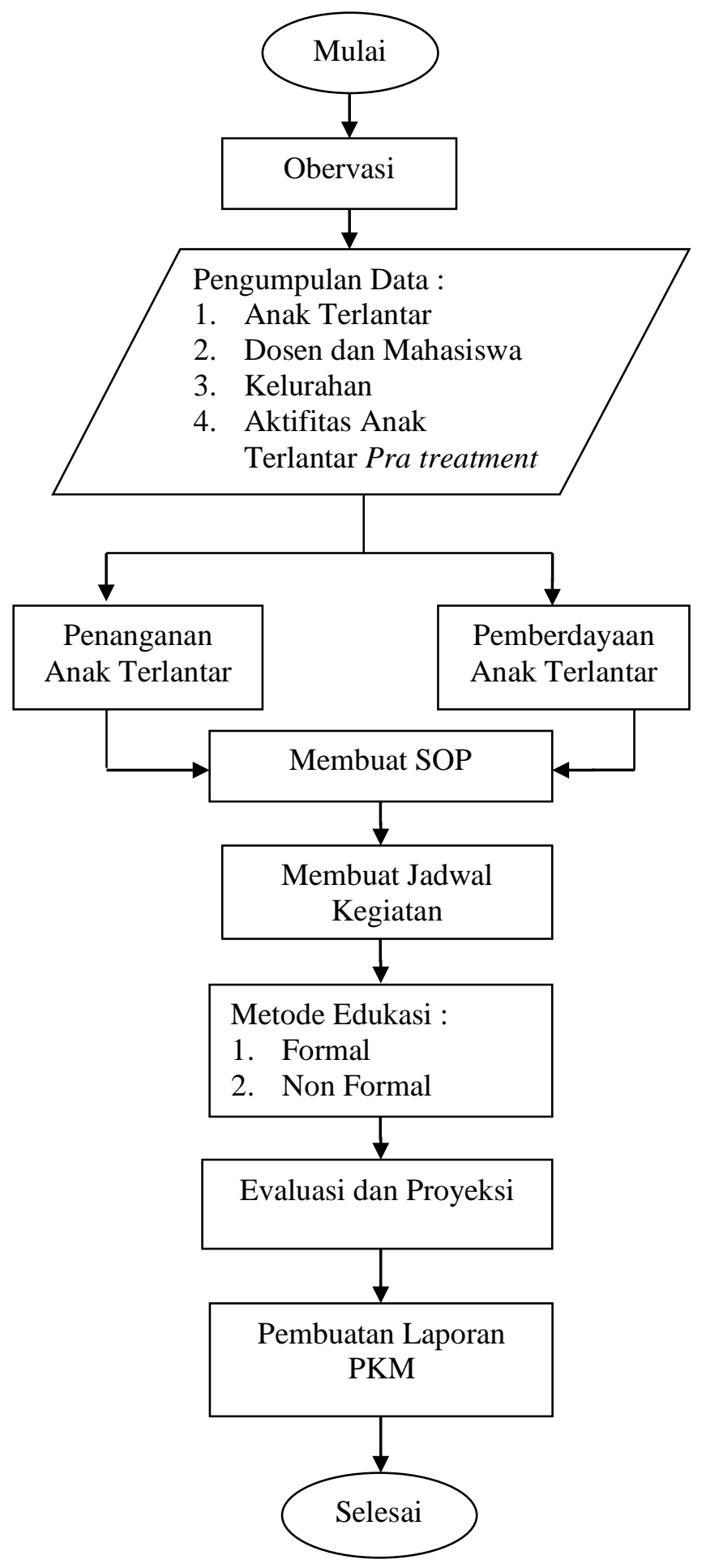

Gambar 1 Flow Chart pelaksanaan pembinaan anak terlantar 
Standart Operating Procedure (SOP) "Rumah Singgah Peduli Anak Penerus Bangsa".

A. Kehadiran dan Kepulangan

1. Kehadiran
a. Waktu Kehadiran
Selambat-lambatnya pukul 01.00 WITA.
b. Aktivitas Awal Kehadiran
Senyum, salam, sapa dan bersalaman.

2. Kepulangan

a. Waktu pulang pukul 05.00 WITA.

b. Sebelum pulang merapikan rumah singgah terlebih dahulu.

c. Hal-hal yang berkait dengan kehadiran dan kepulangan, dkerjakan mengikuti poin-poin yang ada.

B. Penyambutan Anak Didik

1. Sambutan kepada anak didik dengan tujuan agar semua murid merasakan perlakuan khusus dan pengistimewaan.

2. Menyambut dengan berdiri dengan memberikan sambutan senyum, salam, sapa dan bersalaman dengan anak didik.

C. Kegiatan Proses Belajar Mengajar

1. Kegiatan PBM sebelum pukul 01.00 WITA, Dosen dibantu mahasiswa masuk dengan menyiapkan perlengkapan belajar yang diperlukan.

2. Pelaksanaan PBM

a. Melibatkan mahasiswa untuk memulai perjumpaan di kelas dengan ice breaking seperti: sekilas info, tebak-tebakan, joke, permainan dan lain-lain, yang bertujuan untuk mendapatkan perhatian anak dan mencairkan suasana.

b. Dosen dan mahasiswa melaksanakan PBM dengan unsur PAIKEM (Pendidikan Aktif, Inovatif, Kreatif, Efektif dan Menyenangkan).

c. Menutup pelajaran dengan hamdalah dan salam.

d. Dosen dan Mahasiswa tidak memperbolehkan anak didik keluar sebelum pukul 05.00 WITA, kecuali seijin Dosen dan Mahasiswa yang bertugas untuk melatih kedisiplinan

\section{Hasil dan Pembahasan}

Pemerintah kota Balikpapan dalam hal ini pihak Kelurahan Baru Ulu telah memfasilitasi terbentuknya Rumah Singgah Peduli Anak Penerus Bangsa dan Pusat Kegiatan Belajar Masyarakat (PKBM). Untuk menghidupkan kegiatannya, maka mahasiswa dan dosen pembimbing lapangan terjun secara langsung mengambil peran aktif sebagai mentor untuk mengisi dan memberikan tambahan ilmu pengetahuan kepada anak-anak.

Pelaksanaan program pengabdian masyarakat telah dilaksanakan sesuai jadwal yang telah disusun. Adapun kegiatan yang telah dilakukan berupa pembelajaran non formal selama jangka waktu Juli hingga Agustus 2019 meliputi:

1. Observasi dan pengumpulan data berupa jumlah anak terlantar, usia anak-anak terlantar dan kegiatan/aktifitas anak-anak tersebut kesehariannya.

2. Membuat jadwal kegiatan yang tidak mengganggu aktivitas pendidikan formal anak-anak.

3. Mengumpulkan anak-anak dan mengelompokkan anak-anak sesuai usia kemudian memberikan tambahan pelajaran sesuai jenjang pendidikan formalnya.

4. Selain tambahan pengetahuan yang diberikan kepada anak-anak tersebut, mereka juga diajarkan hal-hal yang berkaitan dengan perbaikan akhlak dan cara-cara bersosialisasi yang sehat.

5. Kegiatan belajar mengajar dari tanggal 05-19 agustus 2019 anak panji berbakat memiliki daya tangkap yang baik untuk memahami materi-materi yang diajarkan seperti (Kuncahyono, 2017):
a. Bahasa Inggris
b. Matematika
c. Hukum dasar Negara

Dalam proses belajar mengajar di panji berbakat, juga dilakukan evaluasi berupa test akhir pengajaran.

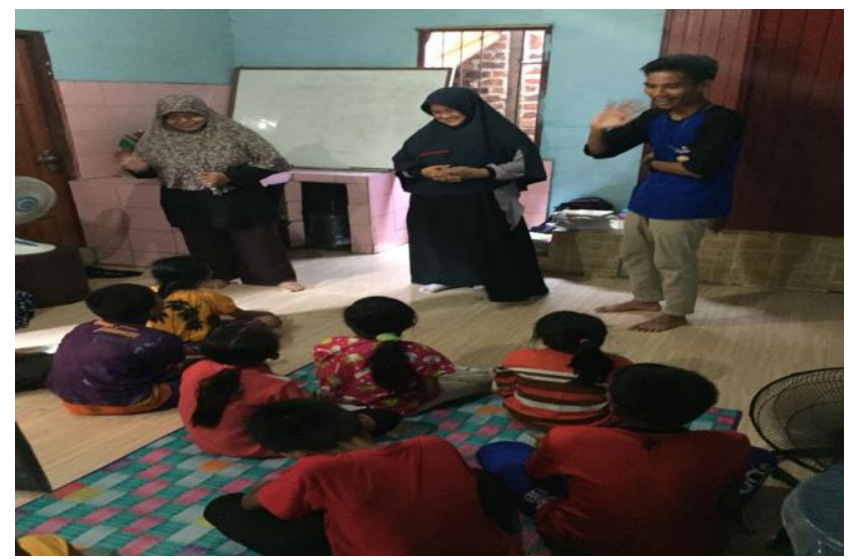

Gambar 2 Proses belajar mengajar

\section{Kesimpulan dan Saran}

Untuk mengarahkan dan membina anak-anak usia dini hingga remaja di daerah atau kawasan kumuh diperlukan perhatian dan kepedulian ekstra dari pihak pemerintah, Lembaga Swadaya Masyarakat (LSM) dan orang-orang yang memiliki kesadaran tinggi untuk peduli terhadap masa depan generasi muda, sehingga terbentuk wadah pembinaan pemberdayaan dan pendampingan anak terlantar penerus bangsa yang 
dinamakan Panji Berbakat. Kegiatan ini dimaksudkan untuk memberikan tambahan ilmu pengetahuan di luar sekolah formal dan mengajarkan nilai-nilai moral untuk memperbaiki akhlak serta membuka dan menambah wawasan anak-anak agar tergerak untuk memperbaiki diri.

Sebaiknya pihak pemerintah dalam hal ini diwakilkan pihak kelurahan dapat meningkatkan dan memfasilitasi program seperti tambahan ilmu dan pembinaan bakat terutama untuk anak terlantar serta mengkontinuitasi kegiatan-kegiatan yang positif secara berkesinambungan.

\section{Ucapan Terima Kasih}

Terima kasih ditujukan kepada LPPM Universitas Balikpapan yang telah memfasilitasi kegiatan KKN dan pihak Kelurahan Baru Ulu Balikpapan.

\section{Daftar Rujukan}

Kamil, Ahmad. (2008). Hukum Perlindungan dan Pengangkatan Anak di Indonesia. Jakarta: Raja Grafindo Persada.

Gultom, Maidin. (2013). Perlindungan Hukum terhadap Anak dan Perempuan. Bandung: Refika Aditama.

Nasir Djamil, M. (2013). Anak Bukan untuk Dihukum. Jakarta Timur: Sinar Grafika.

Undang-Undang Nomor 23 Tahun 2002 tentang Perlindungan Anak.

Fitriani, Rini. (2016). Peranan Penyelenggara Perlindungan Anak Dalam Melindungi Dan Memenuhi Hak-Hak Anak. Jurnal Hukum Samudra Keadilan, II(2), 250-258

Kuncahyono. (2017). Analisis Penerapan Media Berbasis Komputer pada Pembelajaran Tematik Terpadu di Sekolah Dasar Kuncahyono. Jurnal Pemikiran dan Pengembangan SD, 5(2), 773-780.

Syarifuddin. (2015). Motif Penggunaan Teknologi Informasi Dan Motif Use of Information and Communication Technology in Elementary School Children. Jurnal Penelitian Komunikasi dan Opini Publik, 19(1), 43-55 